\title{
AGENCY THEORY, OWNERSHIP STRUCTURE AND CAPITAL STRUCTURE: AN EMPIRICAL INVESTIGATION IN THE INDIAN AUTOMOBILE INDUSTRY
}

\author{
Vibha Tripathi \\ Amrut Mody School of Management, \\ Ahmedabad University, India \\ E-mail: vibha.tripathi@ahduni.edu.in
}

\begin{abstract}
Capital structure is not only the result of the various financial characteristics of the firm but is also determined by the decision makers. The study from the perspective of the Agency Theory, examines the relationship between ownership structure and the capital structure of the Automobile Industry in India from 2001 to 2014 by using panel data analysis. Debt Equity Ratio represented capital structure and Promoters Shareholding wasused as a proxy for ownership structure. The findings of the study after controlling for variables like assets turnover ratio, uniqueness and size reveal that ownership structure has a significant and positive relationship with capital structure showing postulates of the Agency Theory. The findings lend new insights to the fact that a majority of the Indian automobile firms which are family oriented promote the use of debt to mitigate agency costs unlike the popular belief that Indian firms follow the Pecking Order Theory. The existence of the Agency Theory signals to the probable investors about the managers-shareholders as well as shareholders-debtholders relationship, and its impact on company's debt taking capacity.
\end{abstract}

Keywords: capital structure, ownership structure, agency theory, panel data

\section{$\underline{\text { ARTICLE INFO }}$}

Article History:

Received: 28 October 2018

Accepted: 31 May 2019

Published: 31 August 2019 


\section{INTRODUCTION}

The capital structure of a firm is made up of equity, retained earnings and debt. These three major components somewhere depict the firm ownership structure in the sense that equity and retained earnings reflect shareholder's ownership while debt represents the ownership of external agencies. This pattern is found both in developing and developed countries. Owing to this fact, the financing policy, capital structure and firm ownership are all strongly inter linked in explaining how managers, who are the agents employed to work for maximizing the returns to the shareholders, modify their behavior in acquiring good projects for the company and influence the returns in the form of direct remuneration, capital gains or dividends. "Capital structure is not only the result of the various financial characteristics of the firm; it is also determined by the decision-makers' choice. Both managers and significant outside owners exert a major influence on decisionmaking in the firm and, consequently on financing decisions." (Pindado \& de La Torre, 2011) The rise of the Modern Corporation, with its separation of owners from the management, has created a set of agency problems between shareholders $\&$ the management and between the debtholders $\&$ the shareholders that can cause capital structure decisions to deviate from what is expected from neoclassical models. Managers may not always work for the benefit of the shareholders. Against this backdrop, Jensen and Meckling (1976) were among the first authors to give the concept of Agency Theory of capital structure. The managers in firms may invest in negative projects out of the available free cash flow to gain personal perks. This may result in high agency costs to the firms. Debt is one of the important factors that alleviates the agency cost problems arising between shareholders and the managers as the debtholders will monitor the managerial actions and create a soft pressure to perform well to pay the fixed obligations. However higher debt may result into financial distress and loss of jobs for the managers. It may also elevate the problems between the debtholders and the shareholders of the company. Thus, managers may opt for lower debt ratios to avoid bankruptcy risks.

Businesses starts as proprietorship, partnership, or closely held limited company in India. However, when the business attains economies of scale, for growth; the firms need to adopt the Initial Public Offering (IPO) route. With this, the first stage of diffusion of ownership starts. Consequently, it 
then further opts for issue of share capital depending on the requirement of funds for capital investment and other factors such as choice of capital structure, signalling impact of new issue, etc. The owners of the closely held companies taking them to the stage of IPO are known as 'promoters' in the Indian context. They are considered insiders until they cease to retain control over the Board of Directors. The shareholding has been classified in Table 1 according to the standard taxonomy of investor's categories and definitions as provided under Clause 35 and $40 \mathrm{~A}$ of the listing agreement.

Table 1: Shareholding Classification

\begin{tabular}{|c|c|}
\hline Promoters Equity Holding & $\begin{array}{l}\text { Indian promoters holding } \\
\text { Foreign promoters holding } \\
\text { Persons Acting in concert }\end{array}$ \\
\hline Non Promoters holding: Institutions & $\begin{array}{l}\text { Mutual Funds, Unit Trust of India (UTI) } \\
\text { Banks } \\
\text { Financial Institutions } \\
\text { Insurance companies } \\
\text { Foreign Institutional investors (FIIs) }\end{array}$ \\
\hline $\begin{array}{l}\text { Non Promoters holding: Non } \\
\text { Institutions }\end{array}$ & $\begin{array}{l}\text { Corporate Bodies } \\
\text { Individual (Indian Public) } \\
\text { Others }\end{array}$ \\
\hline
\end{tabular}

The persons or bodies other than the promoters having investment in the share capital are 'non-promoter' or 'non-promoter shareholders'. (Ganguli, 2009).

\section{RATIONALE OF SELECTING THE AUTOMOBILE INDUSTRY IN INDIA}

Recently many Indian firms have faced bankruptcy issues due to the over reliance on debt or due to improper capital structure decisions. For an emerging economy like India it becomes important for the Indian manufacturing firms to have an optimal capital structure. With strong backward and forward linkages, the automobile sector has been identified as one of the sunrise industries in the manufacturing sector. The automobile industry currently contributes $49 \%$ of the manufacturing GDP and $7.5 \%$ of the country's GDP (Source: SIAM). 
Demographically and economically, India's automotive industry is well poised for growth, servicing both domestic and global markets. The companies benefiting most from this evolving landscape would be the ones who prepare for the growing importance of green technologies, and who remain flexible enough to respond to the twin needs of private light transport and mass transport schemes (Source: KPMG, Auto Survey). To cash in on these opportunities, companies will have to invest heavily in Technology, Research \& Development, and Assets, which will further compel the companies to raise funds through debt or equity and strategize their capital structure to ensure financial benefits. Capital-intensive industries tend to have higher debt-to-equity ratios than low-capital industries because capitalintensive industries are compelled to purchase more property, plants, and equipment to operate.

The debt equity ratio (capital structure) of Automobile Industry ranges between 30 to $70 \%$ from 2001-2014 and as of 2015 it was 45\% (Source: CMIE prowess database).

The findings till now suggest that Indian firms follow the Pecking Order Theory (Babu \& Jain, 1998), where internal funds are given more preference than external funds for fulfilling the capital requirements of the firm. But the debt to equity ratio over the period of study clearly shows that debt as a choice of fund in the total capital structure is gaining popularity amongst these firms. Also, empirical evidence suggest a mix of Pecking Order and Trade Of Theories in Indian manufacturing irms (Chadha \& Sharma, 2015; Jackling \& Johl, 2009). If the agency problems are absent, capital structure should be expected to be independent from the structure and concentration of ownership. The argument is that if the agency problems can be attributed to the fact that firms are incorporated, the financial performance and capital structure decisions cannot be independent from the ownership structure and concentration.

The capital structure components of the selected sample firms has a tilt towards ownership with equity and retained earnings being more than $60 \%$ of the total funds (Source: Prowess Database). Also Indian ownership pattern is heavy on the family ownership side (Chakrabarti et al., 2008). Against this backdrop, it would be interesting to know if the capital structure of automobile firms which are cyclical in nature and capital intensive, can 
be influenced by the change in the ownership pattern in these firms with some traces of the Agency Theory.

\section{LITERATURE REVIEW}

Since the inception of the idea of separation of ownership from management in companies, the burning issue of agency cost has never settled down and even flags high. Various attempts of internal and external structures such as laws, ethics corporate governance and ownership dispersion have been developed to address this agency problem. The present study found a positive relationship with capital structure. Similar results were found by Ganguli (2013) in the Indian context. Based on the Agency Theory, the findings indicated that the ownership structure does impact capital structure but not the vice versa i.e. leverage had a positive relationship with concentrated shareholding and had a negative relation with diffuseness of shareholding after controlling for profitability, risk, tangibility, growth, and size. Gill et al. (2015) investigated the relationship between capital and promoters shareholding and predicted that managers may take debt to please the shareholders but the risk of bankruptcy is always there and concluded that a change in promoter ownership played a significant role in reducing debt. Tawiah et al. (2014) found a strong relationship between promoter ownership structure and board composition and argued that high promoter concentration is a contributing factor for more promoters on the board of the companies. Previous research reported that the old companies in the Automobile industry are family dominated ownership in the form of promoters (Tawiah et al., 2014). Kalashree and Rajashekar (2014) argued that the shareholding is concentrated in the hands of the promoters and this has low to moderate relationship with size of the board. Reddy and Locke (2013) observe that an increase in independent directors, board member experience, size of company, borrowing from members rather than banks; reduces agency costs and increases profitability in firms in New Zealand. Kumar (2012) advocated that the shareholding by institutional investors and managers affect firm performance while the equity ownership by foreign and corporate shareholders do not influence firm performance However, there was no evidence in favour of endogeneity of ownership structure significantly. Huang, Lin and Huang (2011) revealed ownerships of state and institutions have a positive effect on corporate leverage in high-leveraged 
companies but not in low-leveraged firms. Pindado and de La Torre (2011) in a study of Spanish companies, points out that capital structure is partly determined by the incentives and the goals of those who are in control of the firm because of managerial entrenchment and rent expropriation phenomena. Additionally, they found evidence of an interaction effect between managerial ownership and ownership concentration, in particular, the larger debt increments promoted by outside owners when managers are entrenched. In Indian companies, Ganguli and Agrawal (2009) show that there is negative relationship between performance and diffused shareholding for Indian companies. The empirical evidence showed that there is a dominance of concentrated holding pattern in Indian context and found positive relationship between firm performance and concentration of holding and vice versa. Lakshmi (2009) found a significant but negative relationship between the ownership structure (represented by promoter's shareholding) and the capital structure. The firm specific variables like size, growth, profit, tangibility, and business risk were found to be statistically significant. Business risk and debt employed were positively related while Growth options and non-debt tax shields were statistically significant in explaining the cross sectional differences in the capital structure. Kaur and Gill (2009) observed that there is an insignificant shareholding of individuals and a fall in the proportion of outstanding shares held by banks, insurance companies, and corporate bodies from 2001-06. In addition, ownership concentration increased over a period and Indian promoters had the highest stake in $54 \%$ of all the cases while foreign promoters just held $12 \%$.

In the Russian context, Poyry and Maury (2010) analysed the state controlled firms and found that firms with the state as controlling shareholder have significantly higher leverage than firms controlled by domestic private controlling shareholders other than oligarchs. The study showed that profitability is negatively related to leverage across all types of controlling owners, indicating pecking order theory. Al-Najjar and Taylor (2008) found that ownership structure has a strong effect on the capital structure choice of Jordanian firms. Jordanian firms institutional capital and ownership structure were determined jointly by assets tangibility, firm size, growth opportunities, and business risk are considered. Abor (2007) in their seminal contribution, found that Ghanaian listed firms pursue high debt policy with larger board size, higher percentage of non-executive directors, and CEO duality. The results also showed a negative relationship between the tenure of the CEO 
and capital structure, suggesting that entrenched CEOs employ lower debt in order to reduce the performance pressures associated with high debt capital. A study by Selarka (2005) found interesting results that showed insider ownership in group firms in Indian corporates is much lower when the relation between firm value and insider ownership becomes positive. One of the implications of this finding is that the securities market signals the expropriation motives of stand-alone firms, which are relatively smaller and younger, until the insiders own such a stake where expropriation may cause huge wealth loss. The research also showed evidence of managerial entrenchment in private corporate bodies. Ang, Cole, and Lin (2000) revealed that agency costs are higher when an outsider manages the firm, agency costs vary inversely with the manager's ownership share, external monitoring by banks may lower the agency costs, and that monitoring on managers expenditures on perquisites and other personal consumption relies on vigilance by third parties. Their findings were in line of Jensen and Meckling (1976) and Fama and Jensen (1983). Agrawal and Nagarajan (1990) in their study of equity based firms in India found that managerial control of voting rights and family relationships among senior managers are important factors in the decision to eliminate leverage. Results confirmed that top managers of all-equity firms with family involvement in corporate operations have greater control of corporate voting rights, than managers of all-equity firms without family involvement. Agarwal and Knoeber (1996) conducted a study on firm performance and mechanisms to control agency problems and found interdependence between the seven mechanisms namely shareholdings of insiders, institutions, and large block holders, use of outside directors, debt policy, the managerial labour market, and the market for corporate control in large firms. Shareholders greater insider ownership was positively related to performance, while more outsiders on the board, more debt financing, and greater corporate control activity were negatively related to performance.

Eminent researchers have explored the relationship between capital structure, ownership structure, and firm value in emerging economies like India and developed economies (UK, US). However, a review of studies in the Indian context showed that most of the researchers have concentrated on the ownership structure (corporate governance) and its impact on firm value (Chadha \& Sharma, 2015; Dawar, 2014; Banerjee \& De, 2014; Jaisawal \& Srivastava, 2013). Apart from a limited amount of empirical research by 
Ganguli (2013) and Lakshmi (2009), there is hardly any empirical evidence that links the ownership structure directly with the capital structure of the companies. The present study attempts to fill this gap by examining the relationship between ownership structure and the capital structure in the automobile industry. Since the ownership structure of Indian automobile companies which are family owned is comparatively very different (Tawiah et al., 2014) from other companies globally, it would be interesting to investigate its relationship with capital structure and find if the Agency Theory exists in these firms.

\section{DATA AND RESEARCH METHODOLOGY}

\section{Sources of Data}

The information relating to the ownership patterns, capital structure, financial ratios and other variables was collected from the latest version of Prowess for Interactive Querying (Prowess IQ), Centre for Monitoring Indian Economy (CMIE). It is a powerful internet-based application for querying CMIE's database on performances of listed and unlisted companies. Established in 1976, CMIE is a leading business information company, which provides financial performance time series data of Indian companies through paid subscription, and its database is updated on a daily basis. Annual Reports of individual companies was the principal source of this database.

\section{Period of the Study}

The Auto Industry saw tremendous changes post liberalization and that too after policies like Auto policy 2002, the growth of the Automobile sector was persistent. Discontinuation of foreign exchange neutrality and approval of $100 \%$ Foreign Direct Investment (FDI) via automatic route were few of the impactful policy decisions which invited more foreign investors in India. Thus the ownership patterns also changed during this period. The period 2001-14 includes both pre and post financial distress (2008) period. Thus the relationship between capital structure and ownership structure was explored for 14 years from 2000-01 to 2013-14 which included all the major amendments of the Automobile Industry (Source: SIAM). 


\section{Sample Selection}

Sample selection consisted of listed Automobile companies on the Bombay Stock Exchange (BSE) from 2000-2001 to 2013-2014. The preliminary list of sample companies was around 44 companies. Firms having missing values in either the dependent variable or independent variables and inactive firms in terms of business operations throughout the period of the study were excluded. The firms were selected based on market capitalization, sales, and net profit and market share as per top BSE 100 AUTO under Auto 2/3 wheelers, Auto LCVs and HCVS and Auto Cars and Jeeps.

\section{Theoretical Framework}

Promoters Shareholding was used as a proxy for ownership structure to investigate its impact on capital structure. However, capital structure is affected by number of other factors, hence, the need for control variables to be included in the model. But these control variables were treated in the same way as explanatory variables and discussed in detail. The details of the variables used in the study is presented in Table 2

Table 2: Description of the Variables

\begin{tabular}{lllc}
\hline Variables & \multicolumn{1}{c}{ Definition } & \multicolumn{1}{c}{ Measurement } & $\begin{array}{c}\text { Dependent/ } \\
\text { Independent/ } \\
\text { control }\end{array}$ \\
\hline DE & Debt Equity Ratio & $\begin{array}{l}\text { Debt/Total Equity is used as a proxy } \\
\text { for capital structure }\end{array}$ & $\mathrm{D}$ \\
\hline PSH & Promoters Shareholding & $\begin{array}{l}\% \text { of Promoters to total shareholding } \\
\text { was used as a proxy for ownership } \\
\text { structure }\end{array}$ & $\mathrm{I}$ \\
\hline ATR & Assets turnover Ratio & Net sales /average total assets & $\mathrm{C}$ \\
\hline UNI & Uniqueness & $\begin{array}{l}\text { Selling and distribution expense as a } \\
\text { percentage of net sales }\end{array}$ & $\mathrm{C}$ \\
\hline Size & Size & Natural logarithm of total assets & $\mathrm{C}$ \\
\hline
\end{tabular}

$\mathrm{D}=$ Dependent; $\mathrm{I}=$ Independent; $\mathrm{C}=\mathrm{Control}$

Objective: To investigate the relationship between the ownership structure and the capital structure of the Automobile Industry in India. 


\section{Hypothesis}

$\mathbf{H}_{0} \quad$ There is no significant relationship between ownership structure and capital structure of the automobile industry as a whole in India.

For the dependent variable debt equity ratio the null hypothesis (sub hypothesis) mentioned in Table 3 was tested for each of the explanatory variables:

Table 3: Sub Hypothesis

\begin{tabular}{ll}
$\mathrm{H}_{01}$ & $\begin{array}{l}\text { There is no significant relationship between promoters shareholding and } \\
\text { debt equity ratio }\end{array}$ \\
\hline $\mathrm{H}_{02}$ & $\begin{array}{l}\text { There is no significant relationship between the assets turnover ratio and } \\
\text { debt equity ratio }\end{array}$ \\
\hline $\mathrm{H}_{03}$ & $\begin{array}{l}\text { There is no significant relationship between the uniqueness and debt equity } \\
\text { ratio }\end{array}$ \\
\hline $\mathrm{H}_{04}$ & There is no significant relationship between the size and debt equity ratio \\
\hline
\end{tabular}

For analysing the impact of ownership structure on Capital structure (DE) following panel regression models have been developed:

$D E$ it $=\beta o+\beta 1(P S H) i t+\beta 2($ ATR $) i t+\beta 3($ UNI)it $+\beta 4($ SIZE) it + cit

\section{Pooled Model (1)}

$D E$ it $=\beta o i+\beta 1(P S H) i t+\beta 2(A T R) i t+\beta 3($ UNI)it $+\beta 4($ SIZE $) i t+$ uit

\section{Fixed Effect Model (2)}

Where,

DE it $\quad=$ Debt equity ratio of firm $\mathrm{i}$ at time $\mathrm{t}$.

PSH it $=$ Promoters shareholding of firm $i$ at time $t$.

ATR it $=$ Assets Turnover Ratio of firm $\mathrm{i}$ at time $\mathrm{t}$

$\mathrm{UNI}$ it $=$ Uniqueness of firm $\mathrm{i}$ at time $\mathrm{t}$.

SIZE it $=$ Size of firm $i$ at time $t$.

Bo $=$ common y-intercept. 


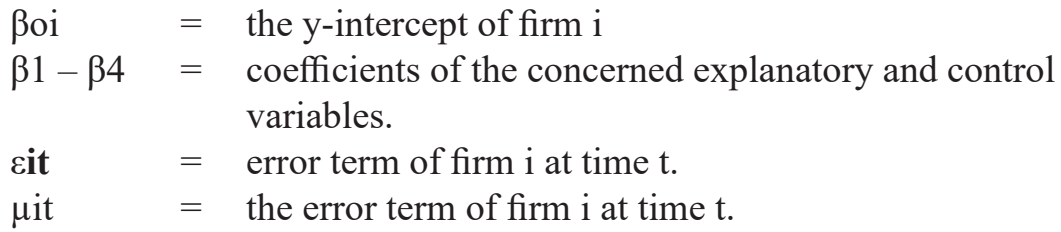

\section{Research Methodology}

Panel data procedures were applied because the sample contained both cross section data and time series data. Taking the sample companies as the representative of the automobile industry, Panel Data regression was used across 10 leading companies for 14 years. These companies cover $92 \%$ of the market share (SIAM, 2015). The use of panel data increased the sample size considerably and is more appropriate to study the dynamics of change (Gujarati, 2012). Panel data by blending inter individual differences and intra individual dynamics have advantages over cross sectional or time series data. Panel data usually contain more degrees of freedom and more sample variability than cross sectional data or time series. It controls the impact of omitted variables i.e. reduces omitted variable bias.

\section{Methodology and Model Estimation}

Under the hypothesis that there are no groups or individual effects among the firms included in the sample, first estimated pooled OLS model was used. Since panel data contains observations on the same cross-sectional units over several time periods there might be cross-sectional effects on each firm or on a set of group of firms. Therefore, the Lagrange Multiplier test was applied to see which model is better Pooled/Ordinary Least square or Panel. Table 9.26, shows the results of the Lagrange multiplier test as significant $(21.883 / 0.0000)$ at $5 \%$, suggesting the suitability of panel models over the pooled model. Further panel data have cross section effects, either fixed or random. The Fixed Effect redundant Test was applied and the results of the Test were significant suggesting the use of the Fixed Effect Model (FEM). Descriptive Statistics, Correlation Matrix, and VIF values have also been presented for each of the variables. The data analysis was been done with the help of the statistical software E-Views and SPSS. 


\section{Descriptive Statistics}

Table 4 provides a summary of the descriptive statistics of the dependent and independent variables. The maximum and minimum values and the standard deviations for each of the variable are also presented in Table 4 . The mean debt equity ratio of the firms is 0.5581 . This suggests that total debt appears to constitute more than half of the capital of the firms i.e. $55 \%$ of total assets are financed by debt capital and the rest $45 \%$ by other sources. The maximum value is 3.55 and the minimum value is 0 .

The mean Promoters shareholding is 49.46, which shows almost $50 \%$ of the shareholding in the Indian automobile firms constitutes of promoters shareholding. This means the remaining 50\% is non -promoter's shareholding. The minimum and maximum value shows that in the Automobile Industry minimum Promoters to total shareholding is $4.87 \%$ and while the maximum percentage is 76.69 . The standard deviation is 13.81 showing huge variations. Assets turnover ratio taken as sales to average total assets registers a mean value of 1.628. It has a maximum ratio of 3.48 and minimum 0.63 . Mean of uniqueness given as a ratio of selling $\&$ distribution to $\%$ of net sales is 5.55 . The maximum value is 12.17 and the minimum value is 0.56 . Firm size determined as the natural logarithm of total assets has a mean of 9.95. Maximum value is 13.22 and minimum value is 5.25.

Table 4: Descriptive Statistics

\begin{tabular}{lccccc}
\hline & DE & PSH & ATR & UNI & Size \\
\hline Mean & 0.558143 & 49.46521 & 1.628 & 5.557286 & 9.952804 \\
\hline Median & 0.44 & 54.21 & 1.47 & 5.01 & 10.17399 \\
\hline Maximum & 3.55 & 76.79 & 3.48 & 12.17 & 13.22551 \\
\hline Minimum & 0 & 4.87 & 0.63 & 0.56 & 5.254365 \\
\hline Std. Dev. & 0.517556 & 13.81409 & 0.637766 & 2.631846 & 1.883013 \\
\hline
\end{tabular}

Sources: CMIE Prowess; statistical tool: E-Views

\section{Correlation Analysis}

Table 5 represents the correlation matrix between variables. Debt Equity ratio is negatively correlated with the Promoters shareholding but 
is insignificant at the $5 \%$ level. Debt equity ratio is negatively correlated with Assets Turnover Ratio and significant at the 1\% level. It is positively correlated with uniqueness and signicant at $5 \%$. It is negatively correlated with size. Within the independent variables promoter's shareholding is positively correlated with the Assets Turnover Ratio and significant at the $1 \%$ level. PSH is negatively correlated with size and significant at the $1 \%$ level and positively correlated with uniqueness. Assets turnover ratio and size are negatively correlated and significant at the $1 \%$ level.

Table 5: Correlation Matrix

\begin{tabular}{|c|c|c|c|c|c|c|}
\hline & & $\mathrm{DE}$ & PSH & ATR & UNI & SIZE \\
\hline \multirow{2}{*}{ DE } & Pearson Correlation & 1 & & & & \\
\hline & Sig. (2-tailed) & - & & & & \\
\hline \multirow{2}{*}{ PSH } & Pearson Correlation & -.090 & 1 & & & \\
\hline & Sig. (2-tailed) & .288 & - & & & \\
\hline \multirow{2}{*}{ ATR } & Pearson Correlation & $-.314^{* *}$ & $.449^{* *}$ & 1 & & \\
\hline & Sig. (2-tailed) & $(.000)$ & $(.000)$ & - & & \\
\hline \multirow{2}{*}{ UNI } & Pearson Correlation & $.179^{*}$ & .048 & -.008 & 1 & \\
\hline & Sig. (2-tailed) & $(.034)$ & .570 & .925 & - & \\
\hline \multirow{2}{*}{ SIZE } & Pearson Correlation & -.071 & $-.384^{* *}$ & $-.363^{* *}$ & .122 & 1 \\
\hline & Sig. (2-tailed) & .407 & $(.000)$ & $(.000)$ & .152 & - \\
\hline \multicolumn{7}{|c|}{${ }^{* *}$. Correlation is significant at the 0.01 level (2-tailed). } \\
\hline \multicolumn{7}{|c|}{ *. Correlation is significant at the 0.05 level (2-tailed). } \\
\hline \multicolumn{7}{|c|}{$P$ values are in parentheses } \\
\hline
\end{tabular}

\section{Empirical Results and Discussion}

Results of fixed effect redundant test are reported in Table 7 and the $\chi^{2}$ (df 9) value (5.30/0.0000) indicates that the null hypothesis of no crosssection fixed effect is rejected and supports panel data fixed effect model over the pooled model. In addition, the value of $\mathrm{R}^{2}$ for the fixed effects estimation model (43\%) is higher than Pooled OLS Model (21\%), indicating the existence of the omitted variables. However, to have a comparative analysis, regression results of both Pooled and Fixed Effect Model 1 and 2 are presented in Tables 6 and 7. 
Table 6: Regression Results - Pooled Model

[Dependent Variable: Debt Equity Ratio]

\begin{tabular}{|c|c|c|c|c|c|}
\hline Variable & Coefficient & Std. Error & t-Statistic & Prob & VIF \\
\hline $\begin{array}{l}\text { P R O M O T E R S } \\
\text { SHAREHOLDING }\end{array}$ & -0.00135 & 0.00186 & -0.7247 & 0.46990 & 1.360 \\
\hline $\begin{array}{l}\text { ASSETS TURNOVER } \\
\text { RATIO }\end{array}$ & -0.17914 & 0.039732 & -4.50872 & 0.00000 & 1.324 \\
\hline UNIQUENESS & 0.028284 & 0.008477 & 3.336423 & 0.00110 & 1.026 \\
\hline SIZE & -0.03826 & 0.013168 & -2.90564 & 0.00430 & 1.267 \\
\hline C & 0.980886 & 0.190014 & 5.162166 & 0.00000 & \\
\hline $\begin{array}{l}\text { Total panel (balanced) } \\
\text { observations }\end{array}$ & 140 & & & & \\
\hline Cross-sections included & 10 & & & & \\
\hline Periods included & 14 & & & & \\
\hline R-squared & 0.213052 & & & & \\
\hline Adjusted R-squared & 0.189735 & & & & \\
\hline F-statistic & 9.137214 & & & & \\
\hline Prob(F-statistic) & 0.000001 & & & & \\
\hline Durbin-Watson stat & 1.762395 & & & & \\
\hline
\end{tabular}

Sources: CMIE Prowess; statistical tool: E-Views

Table 7 reveals the results of the Fixed Effect Model 2, and it has been found that there is a significant relationship between Promoters shareholding and debt equity ratio as the p value of $0.0158<0.05$. Thus, the null hypothesis is rejected that there is no significant relationship between ownership structure and capital structure of the Automobile Industry. Ownership structure has a positive relationship with capital structure showing its direct impact on the capital structure of the Indian automobile industry and emphasizes the fact of usage of debt to mitigate agency costs in the automobile firms. These results are consistent with previous studies (Agarwal \& Knoeber, 1996; Ganguli, 2013; Abor, 2007; King \& Santor, 2008; Alipour, 2015; Owolabi \& Inyang, 2013). Figure 1 depicts the agency cost theory model in detail with the positive and negative relationship outcomes between capital and ownership structure.

According to the fixed panel data regression results in Table 7, Promoters Shareholding and Assets Turnover Ratio are significant in determining the capital structure of the automobile industry as a whole. Uniqueness and size are not significant at the 5\% level. R2 value shows 
the combined effect of the model. It reveals that capital structure has $42 \%$ variation due to the explanatory variables used in the model.

Additionally F-statistics value accept the fitness of the model. The Durbin Watson test result is within the acceptable range of 1-3 and suggests there is no auto correlation problem. The VIF value of all the variables are under the acceptable limit. $(\mathrm{V}<10)$ showing no serial multi collinearity problem.

Table 7: Regression Results - Fixed Effect Model [Dependent Variable: Debt Equity Ratio]

\begin{tabular}{|c|c|c|c|c|c|}
\hline Variable & Coefficient & Std. Error & t-Statistic & Prob. & VIF \\
\hline $\begin{array}{l}\text { PROMOTERS } \\
\text { SHAREHOLDING }\end{array}$ & 0.006217 & 0.002541 & 2.446784 & 0.0158 & 1.360 \\
\hline $\begin{array}{l}\text { ASSETS TURNOVER } \\
\text { RATIO }\end{array}$ & -0.16879 & 0.046739 & -3.6114 & 0.0004 & 1.324 \\
\hline UNIQUENESS & 0.02257 & 0.01292 & 1.74689 & 0.0831 & 1.026 \\
\hline SIZE & -0.02635 & 0.030453 & -0.86527 & 0.3885 & 1.267 \\
\hline C & 0.503076 & 0.352619 & 1.426686 & 0.1561 & \\
\hline $\begin{array}{l}\text { Total panel (balanced) } \\
\text { observations }\end{array}$ & 140 & & & & \\
\hline Cross-sections included & 10 & & & & \\
\hline Periods included & 14 & & & & \\
\hline R-squared & 0.429125 & & & & \\
\hline $\begin{array}{l}\text { Adjusted } \\
\text { R-squared }\end{array}$ & 0.370225 & & & & \\
\hline F-statistic & 7.285664 & & & & \\
\hline Prob (F-statistic) & 0.000000 & & & & \\
\hline Durbin-Watson stat & 1.847267 & & & & \\
\hline $\begin{array}{l}\text { LaGrange Multiplier test/ } \\
\text { prob }\end{array}$ & $21.883 / 0.0000$ & & & & \\
\hline \multicolumn{6}{|l|}{ Redundant Fixed Effects } \\
\hline \multicolumn{6}{|l|}{ Tests Statistic/prob } \\
\hline Cross-section F & $5.30 / 0.0000$ & & & & \\
\hline Cross section X2 (df 9) & $44.94 / 0.000$ & & & & \\
\hline
\end{tabular}

Sources: CMIE Prowess; statistical tool: E-Views 
Control Varibles: Assets Turnover Ratio shows a negative relationship with capital structure (Reddy \& Locke, 2014), thus emphasizing the fact that efficient utilization of assets results into enhanced profitability, which may lead to low requirement of external debt. Uniqueness has a positive relationship in the Automobile Industry as a whole thus supporting the fact that firms with unique products may require more finance and therefore they would opt for debt in market. These results are surprising as previous studies showed a negative relationship (Chaddha \& Sharma, 2014; Harris \& Raviv, 1991; Titman \& Wessels, 1988; Majumdar \& Chibber, 1999; Bhaduri, 2002; Purohit \& Khanna, 2012). Size has a significant but a negative relationship with capital structure which signals postulates of the Pecking Order Theory consistent with the results of previous studies (Chadha \& Sharma, 2015; Purohit \& Khanna, 2012; Alipour et al., 2015)

\section{CONCLUSIONS}

A vast literature has investigated the relationship between capital structure and performance and between ownership structure and firm performance. While most of these studies explore the relationship in the developed countries, little is empirically known about such implications in emerging economies such as India. Thus deviating from the existing research, this study investigated the relationship between capital structure and ownership structure from 2001-2014 in the Indian automobile industry.

The empirical results clearly reveal that ownership structure had a significant impact on the capital structure of the automobile industry as a whole. The empirical results indicate that after controlling variables such as ATR, uniqueness, and size ownership structure has a positive relationship with capital structure of the automobile industry in India.

A positive relationship shows postulates of agency costs. Two important conclusions can be derived from this relationship. In order to restrain the managers from using free cash flows in negative projects, the promoters of the automobile firms opt for debt. Taking debt will not only result in the tax shield benefits but will also compel managers to increase the profitability thereby increasing the firm value and decrease the activities of manager's engagement for personal perquisites. External monitoring from 
the debtholders puts a soft pressure on managers to perform well as debt brings in fixed financial obligations which will enforce the managers to take up only profitable projects. Positive relationship between capital structure and ownership structure also indicates the Signalling Theory (Ross, 1977). According to Ross, debt gains investors' confidence in the company. It gives a signal to the markets that the firm is expecting positive cash flows in near future, as the principal and interest expenses on debt are a fixed contractual compulsion that a firm has to pay from its cash flows. Investors know that only firms with good prospects can afford to take on debt, they recognise debt issuance as a good news and so bid up the firms shares.

The existence of the Agency Theory signals the investors about the managers-shareholders as well as shareholders and debtholders relationship and its impact on company's debt taking capacity. As the ownership structure (promoter's shareholding) has a significant impact on the capital structure of the automobile industry, investors can see the pattern of promoter's shareholding viz. Indian promoters holding, foreign promoters holding and persons acting in concert and then make the investment decisions accordingly. Also further if the ownership structure and capital structure can be studied for the whole manufacturing industry, it may give more concrete reasons of existence of agency theory in Indian firms. 


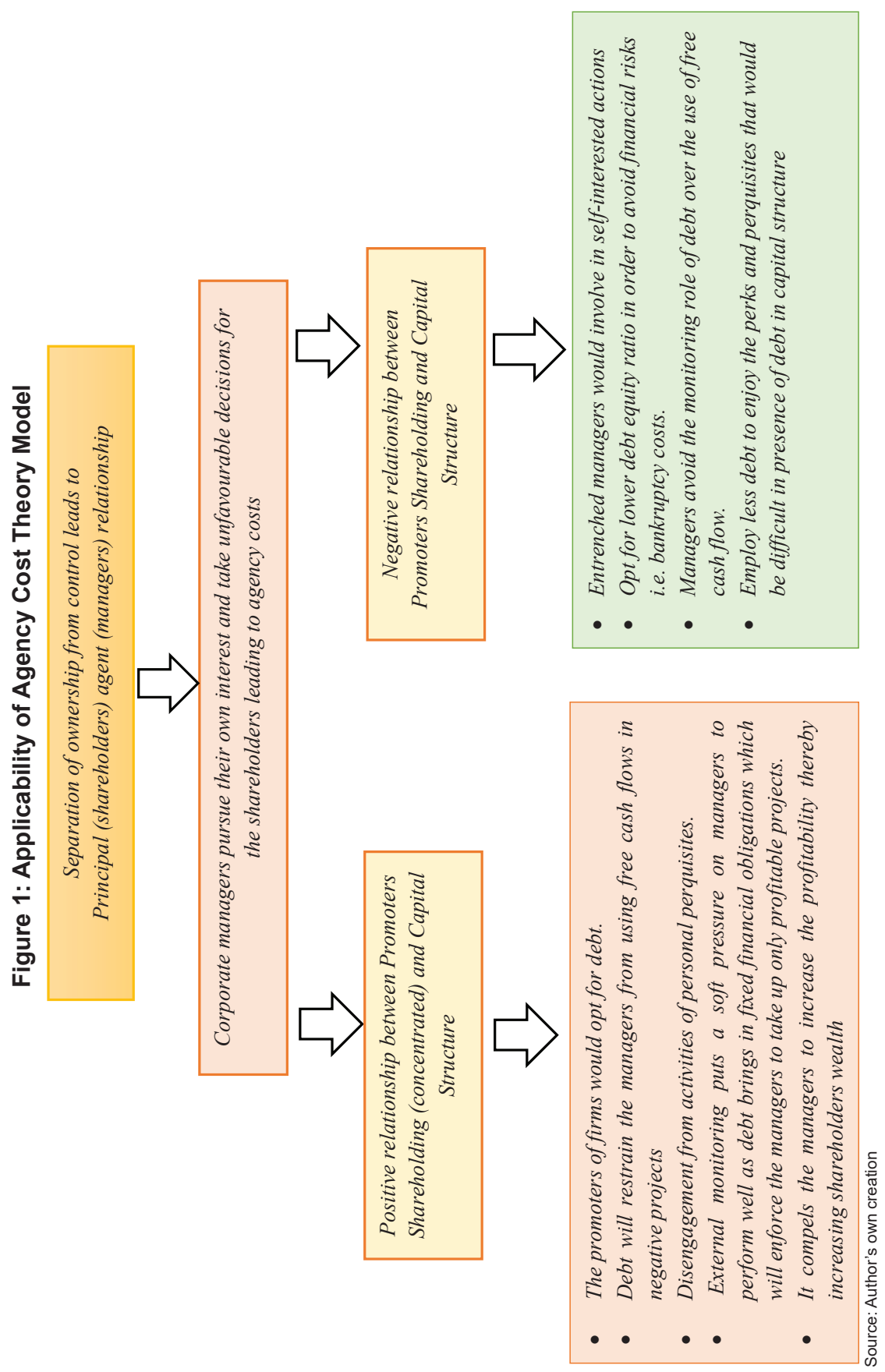




\section{REFERENCES}

Abor, J. (2007). Corporate governance and financing decisions of Ghanaian listed firms. Corporate Governance: The International Journal of Business in Society, 7(1), 83-92.

Agrawal, A., \& Nagarajan, N. J. (1990). Corporate capital structure, agency costs, and ownership control: The case of all-equity firms. Journal of Finance, 45(4), 1325-1331.

Alipour, M., Mohammadi, M. S., \& Derakhshan, H. (2015). Determinants of capital structure: An empirical study of firms in Iran. International Journal of Law \& Management, 57(1), 53-83.

Al-Najjar, B., \& Taylor, P. (2008). The relationship between capital structure and ownership structure: New evidence from Jordanian panel data. Managerial Finance, 34(12), 919-933.

Ang, J. S., Cole, R. A., \& Lin, J. W. (2000). Agency costs and ownership structure. Journal of Finance, 55(1), 81-106.

Babu, S., \& Jain, P. K. (1998). Empirical testing of pecking order hypothesis with reference to capital structure practices in India. Journal of Financial Management and Analysis, 11(2), 63-74.

Banerjee, A., \& De, A. (2014). Determinants of corporate financial performance relating to capital structure decisions in Indian iron and steel industry: An empirical study. Paradigm, 18(1), 35-50.

Bhaduri, S. (2002) Determinants of capital structure choice: A study of the Indian corporate sector. Applied Financial Economics, 12, 655-665.

Chadha, S., \& Sharma, A. K. (2015). Capital structure and firm performance: Empirical Evidence from India. Vision, 19(4), 295-302.

Chakrabarti, R., Megginson, W., \& Yadav, P. K. (2008). Corporate governance in India. Journal of Applied Corporate Finance, 20(1), $59-72$. 
Dawar, V. (2014). Agency theory, capital structure and firm performance: Some Indian evidence. Managerial Finance, 40(12), 1190-1206.

Fama, E. F., \& Jensen, M. C. (1983). Separation of ownership and control. Journal of Law and Economics, 26, 301- 325.

Ganguli, S. K. (2013). Capital structure - Does ownership structure matter? Theory and Indian evidence. Studies in Economics and Finance, 30(1), 56-72.

Ganguli, S. K., \& Agrawal, S. (2009). Ownership structure and firm performance: An empirical study on listed Mid-Cap Indian Companies. IUP Journal of Applied Finance, 15(12), 37-52.

Gill, A., Obradovich, J. D., \& Mathur, N. (2015). Promoter ownership and corporate leverage: Evidence from Indian firms. Corporate Ownership \& Control, 12(3), 513-521.

Gujarati, D. N. (2012). Basic econometric. Tata McGraw-Hill Education, Noida.

Harris, M., \& Raviv, A. (1991). The theory of capital structure. Journal of Finance, 46, 297-355.

Huang, B., Lin, C., \& Huang, C. (2011). The influences of ownership structure: Evidence from China. The Journal of Developing Areas, 45(1), 209-227.

Jackling, B., \& Johl, S. (2009). Board structure and firm performance: Evidence from India's top companies. Corporate Governance: An International Review, 17(4), 492-509.

Jaisawal, B., \& Srivastava, N. S. (2013). Role of capital structure in defining financial performance: A study with respect to cement industry in India. International Journal of Applied Financial Management Perspectives, 3(3), 452-467. 
Jensen, M. C., \& Meckling, W. H. (1976). Theory of the firm: Managerial behaviour, agency costs and ownership structure. Journal of Financial Economics, 3(4), 305-360.

Kalashree \& Rajashekar, H. (2014). Ownership pattern and its impact on board structure and CEO-Chairman role duality in pharmaceutical companies in India. Asian Journal of Research in Business Economics and Management, 4(12), 153-167.

Kaur, P., \& Gill, S. (2009). The effects of ownership structure on corporate governance and performance: An Empirical Assessment in India. Research Project, NFCG, 2008, 149.

King, M. R., \& Santor, E. (2008). Family values: Ownership structure, performance and capital structure of Canadian firms. Journal of Banking \& Finance, 32(11), 2423-2432.

Kumar, J. (2012). Does ownership structure influence firm value? Evidence from India. Retrieved from https://econwpa.ub.uni-muenchen.de/econwp/fin/papers/0406/040 6008.pdf

Lakshmi, K. (2009). Ownership structure and capital structure: Evidence from Indian firms (Working Paper). Retrieved from https://www. researchgate.net/publication/22825 2470_Ownership_Structure_and_ Capital_Structure_Evidence_from_Indian_Firms

Majumdar, S. K., \& Chhibber, P. (1999). Capital structure and performance: Evidence from a transition economy on an aspect of corporate governance. Public Choice, 98, 287-305.

Owolabi, S. A., \& Inyang, U. E. (2013). International pragmatic review and assessment of capital structure determinants. Kuwait Chapter of Arabian Journal of Business and Management Review, 2(6), 82-95.

Pindado, J., \& de La Torre, C. (2011). Capital structure: New evidence from the ownership structure. International Review of Finance, 11(2), 213-226. 
Poyry, S., \& Maury, B. (2010). Influential ownership and capital structure. Managerial and Decision Economics, 31(5), 311-324.

Purohit, H., \& Khanna, S. (2012). Determinants of capital structure in Indian manufacturing sector. Asia-Pacific Journal of Management Research and Innovation, 8(3), 265-269.

Reddy, K., \& Locke, S. (2014). The relationship between ownership structure, capital structure and corporate governance practices: A case study of co-operatives and mutual in New Zealand. International Journal of Managerial Finance, 10(4), 511-536.

Ross, S. A. (1977). The determination of financial structure: The incentivesignalling approach. Bell Journal of Economics, 8(1), 23-40.

Selarka, E. (2005). Ownership concentration and firm value: A study from the Indian corporate sector. Emerging Markets Finance and Trade, 41(6), 83-108.

Tawiah, V. K., Benjamin, M., \& Sharma, D. (2014). Board structures in India: Evidence from automobile and IT companies. International Journal of Management and Commerce Innovations, 2(2), 55-63.

Titman, S., \& Wessels, R. (1988). The determinants of capital structure choice. Journal of Finance, 43(1), 1-19. 